\title{
Epidermal growth factor/epidermal growth factor receptor signaling axis is a significant regulator of the proteasome expression and activity in colon cancer cells
}

\author{
Maria-loanna Ellina, Panagiotis Bouris, Dimitrios Kletsas, Alexios J. Aletras, and Nikos K. Karamanos* \\ Biochemistry, Biochemical Analysis and Matrix Pathobiology Research Group, Laboratory of Biochemistry, Department of \\ Chemistry, University of Patras, Patras 26110, Greece \\ *Corresponding author's e-mail address: n.k.karamanos@upatras.gr
}

Published online: October 15, 2014 (version 1)

Cite as: Ellina et al., ScienceOpen Research 2014 (DOI: 10.14293/S2199-1006.1.SOR-LIFE.AACOE6.v2)

Reviewing status: Please note that this article is under continuous review. For the current reviewing status and the latest referee's comments please click here or scan the QR code at the end of this article.

Primary discipline: Life sciences

Keywords: EGF, EGFR, HER2, Proteasome, Nrf2, K-Ras mutation, colon cancer

\begin{abstract}
Colon cancer is the third most common type of cancer worldwide. Epidermal growth factor receptor (EGFR) plays a crucial role in the (patho)physiology of the disease. EGFR controls vital cellular processes, while this action is associated with poor prognosis. In addition, K-Ras mutations are associated with the promotion of the disease and the antiEGFR resistance. The ubiquitin-proteasome system also plays a very important role in cancer, modulating the cell cycle and other cellular processes such as the growth and the survival of cancer cells. Proteasome inhibition affects, in several cases, the action and the protein levels of EGFR. Nevertheless, little is known whether the reversed option is possible. In this study, we therefore investigated the impact of EGF/EGFR signaling axis on gene expression and the proteolytic activity of the proteasome subunits, as well as whether nuclear factor erythroid-derived 2 related factor 2 (Nrf2), an activator of proteasome expression, plays a role in this process. Moreover, we evaluated whether EGF regulates the expression of its own receptor and the proliferation rate of DLD-1 (K-Ras-mutated) colon cancer cells. The obtained data showed that although EGF has no significant effect on the proliferation of DLD-1 colon cancer cells, it significantly upregulates the expression of EGFR as well as the expression and the activity of the proteasome, suggesting that the EGFmediated proteasome activation could possibly lead to enhanced EGFR degradation, leading to auto-regulation of EGF-EGFR pathway. Nrf2 activation did not induce proteasome gene expression.
\end{abstract}

\section{ABBREVIATIONS}

ARE: Antioxidant Response Elements

EGF: Epidermal Growth Factor

EGFR: EGF Receptor
Nrf2: nuclear factor erythroid-derived 2 related factor 2

RTK: $\quad$ Receptor Tyrosine Kinase

TKI: Tyrosine Kinase Inhibitor

ECM: Extracellular Matrix

\section{INTRODUCTION}

Colon cancer is estimated to be one of the most common types of cancer in Europe and the USA [1, 2]. Epidermal growth factor receptor (EGFR) is a cell surface receptor, with a vital role for cancer [3], regulating crucial cell functions and the expression of several extracellular matrix (ECM) molecules [4] which are key players in cancer, as recently reported by our research group [5, 6]. EGFR is one of the four members of the ErbB family, a subgroup of tyrosine kinase receptors. The activation of the receptor is triggered by specific ligands, mainly by EGF [7]. EGFR has the ability to form both homodimers and heterodimers with other members of the ErbB family. The dimerization of the receptor causes crossphosphorylation of its intracellular part and, therefore, the phosphorylated sites of the receptor act as docking sites for several signaling molecules, containing SH2 or PTB binding sites [8]. The activation of such molecules initiates specific signaling pathways, which in turn activate several transcription factors. EGFR mainly uses four signaling pathways: RasRaf-Mek-Erk, PI3K-Akt, Jak-Stat, and PLC $\gamma$-PKC. Another very important and well-studied receptor of the ErbB family is also HER2/neu. Although HER2 has no natural ligands, it remains a key player into the ErbB family due to its ability to form stable heterodimers with the other receptors of the group [9]. Concerning its signaling pathways, HER2 shares almost the same pathways with EGFR. EGFR overexpression has been associated with advanced stages of colon cancer [10]. Due to HER2 heterodimerization with EGFR, a variety of studies in colon cancer examine the effect of the simultaneous inhibition of both receptors. More specifically, the monoclonal 
antibody against HER2, named trastuzumab, in combination with the specific tyrosine kinase inhibitor (TKI) against EGFR, erlotinib, suppressed growth development both in vivo and in vitro. It is noticing that the inhibition of both receptors enhanced the growth suppression as compared to that caused by pertuzumab alone [11]. Mutations are a common phenomenon in colon cancer. K-Ras mutations are well-studied cases in colon cancer. K-Ras mutation rates in colon cancer account for approximately $20-50 \%$ [12-14] of the mutations. The mutation of K-Ras protein has resulted in the constitutive activation of the molecule, which in turn activates other downstream signaling molecules. This may be a mechanism for the resistance to EGFR-targeted therapies. For this reason, the monotherapy with anti-EGFR monoclonal antibodies is not recommended for patients with K-Ras-mutated status [15-19]. The existence of such mutations makes therapies for colon cancer, based on EGFR inhibition, much more complex. The ubiquitin-proteasome system is the main regulator of the non-lysosomatic degradation of a variety of intracellular proteins, including abnormal, misfolded, denatured, or otherwise damaged proteins. The $20 \mathrm{~S}$ proteasome is a $700-\mathrm{kDa}$ protease composed of 28 subunits arranged as a barrel-shaped structure of four heptameric rings. The two outside rings contain one copy each of seven different but related $\alpha$-type subunits. Likewise, both inside rings contain one copy each of seven different but related $\beta$ subunits, where the catalytic sites are located [20]. The proteasome possesses multiple endopeptidase activities including chymotrypsin-like ( $\beta 5$ subunits), trypsin-like ( $\beta 2$ subunits) and caspase-like ( $\beta 1$ subunits) [21]. Proteasome is responsible for the degradation of many intacellular proteins. Through that process, proteasome controls viable cellular functions and is strongly associated with cell survival and antiaging [22]. Proteasome promotes cell survival mainly by regulation of specific transcription factor such as NF-kB, p53, and c-Jun etc. Its ability to promote cell viability makes proteasome a possible target for anticancer therapies. Indeed, in most cases proteasome inhibition leads to cancer cells apoptosis, both in vivo and in vitro. More specifically, in colon cancer cells, proteasome inhibition by MG-132 suppressed proliferation and inducted apoptosis. In other cases, the combined therapy with proteasome inhibitor and other chemotherapeutic agents enhanced the antitumor effects [23, 24]. Nuclear factor erythroid-derived 2 related factor 2 (Nrf2) is a key transcription factor for cell defense mechanisms that regulates the expression of electrophile and xenobiotic detoxification enzymes and drug efflux pump proteins, which confer cytoprotection against oxidative stress and apoptosis in normal cells. Under the basal conditions, the low constitutive amount of Nrf2 is maintained by the Kelchlike ECH-associated protein1 (Keap1)-mediated ubiquitination and proteasomal degradation system, largely localized in the cytoplasm. Interestingly, in some cases the induction of the proteasome and expression is mediated through an Nrf2dependent manner [25], indicating that Nrf2 protective role may be, partly, due to proteasome expression. However, in cancer, the activation of Nrf2 may have different effects. More specifically, Nrf2 promotes cancer cell survival and development [26-28] and, therefore, enhances chemo resistance against anticancer therapies [29, 30]. EGFR is one of the proteins which are subjected to degradation by the proteasome. In several types of cancer, including colon, proteasome inhibition seems to affect the protein levels or the phosphorylation of EGFR [31-33]. Interestingly, several studies demonstrate that the simultaneous EGFR and proteasome inhibition causes enhanced antitumor effects [31, 32, 34], indicating that the combined EGFR/proteasome inhibition could be a possible therapeutic strategy against cancer. However, there are limited data regarding the involvement of EGFR on proteasome subunits' expression and activation. For this reason, in this study we evaluated whether EGF could affect, via EGFR or HER2, the gene expression and activity of the catalytic proteasome subunits in DLD-1 colon cancer cells. Moreover, we evaluated whether the activation of Nrf2 could possibly affect the proteasome. According to EGFR significance in colon cancer, we further investigated the effect of EGF on EGFR as well as cell proliferation.

\section{MATERIALS AND METHODS Chemicals and reagents}

Dubleco's modified Eagle's medium (DMEM) fetal bovine serum (FBS), L-glutamine, sodium pyruvate, penicillin, streptomycin, gentamycin, and amphotericn B were all obtained from Biochrom AG (Berlin, Germany). The selective inhibitor CP-724,714 against HER2/neu was supplied by Selleck Chemicals. EGFR's specific ligand EGF, receptor's selective inhibitor AG1478, as well as the fluorogenic substrate SucLLVY-AMC for 20S proteasome chymotrypsin-like subunit $\beta 5$ (PSMB5) and synthetic Oltipraz were purchased from Sigma Chemical Co. (St Luis, MO, USA). All other chemicals used were of the best commercially available grade.

\section{Cell lines and culture conditions}

DLD-1 (K-Ras mutant) cancer cell line was purchased from the American Type Culture Collection (ATCC) and cultured at $37^{\circ} \mathrm{C}$ in a humidified atmosphere of $5 \%(\mathrm{v} / \mathrm{v}) \mathrm{CO}_{2}$ and $95 \%$ air. Cancer cells were cultured in DMEM supplemented with 10\% FBS,1.0 mM sodium pyruvate, $2 \mathrm{mM}$ L-glutamine, and a cocktail of antimicrobial agents containing $100 \mathrm{IU} / \mathrm{mL}$ penicillin, $100 \mathrm{mg} / \mathrm{mL}$ streptomycin, $10 \mathrm{mg} / \mathrm{mL}$ gentamycin sulfate, and $2.5 \mathrm{mg} / \mathrm{mL}$ amphotericin B. All experiments were conducted in serum-free conditions.

\section{Total RNA isolation and cDNA synthesis}

Total RNA was isolated after cell lysis with guanidine thiocyanate using NucleoSpin RNA II Isolation System MachereyNagal (Germany). All total RNA preparations were free of 
Table 1. Sequence of the primers used for end point and RT-PCR analysis.

\begin{tabular}{|c|c|c|c|}
\hline Gene & & Primer Sequence & Annealing temperature $\left(T_{\text {annealing }}\right)^{\circ} \mathrm{C}$ \\
\hline \multicolumn{4}{|c|}{ End point $P C R$} \\
\hline \multirow[b]{2}{*}{$\beta 5$ subunit } & Sence & 5'-GAG-ATC-AAC-CCA-TAC-CTG-CTA-G-3' & \multirow[b]{2}{*}{$58^{\circ} \mathrm{C}$} \\
\hline & Anti-sence & 5'-AGT-CAC-CCC-AAG-AAA-CAC-AAG-C-3' & \\
\hline \multirow[b]{2}{*}{$\beta 1$ subunit } & Sence & 5'-CAC-CTA-TTC-ACG-ACC-GCA-TT-3' & \multirow[b]{2}{*}{$58^{\circ} \mathrm{C}$} \\
\hline & Anti-sence & 5'-ACG-GCG-AAT-TTG-GGT-ATC-TG-3' & \\
\hline \multirow[b]{2}{*}{$\beta 2$ subunit } & Sence & 5'-ACA-CAG-ACA-TGA-CAA-CCC-AG-3' & \multirow[b]{2}{*}{$58^{\circ} \mathrm{C}$} \\
\hline & Anti-sence & 5'-AGC-CTG-GTC-CCC-TTC-TTG-T-3' & \\
\hline \multirow[b]{2}{*}{ Nrf2 } & Sence & 5'-AAA-CCA-GTG-GAT-CTG-CCA-AC-3' & \multirow[b]{2}{*}{$49^{\circ} \mathrm{C}$} \\
\hline & Anti-sence & 5'-GAC-CGG-GAA-TAT-CAG-GAA-CA-3' & \\
\hline \multirow[b]{2}{*}{ GAPDH } & Sence & 5'-TCA-AGA-TCA-TCA-GCA-ATG-CCT-CC-3' & \multirow[b]{2}{*}{$60^{\circ} \mathrm{C}$} \\
\hline & Anti-sence & $5^{\prime}-A G T-G A G-C T T-C C C-G T T-C A G-C-3^{\prime}$ & \\
\hline \multicolumn{4}{|l|}{$R T-P C R$} \\
\hline \multirow[b]{2}{*}{ EGFR } & Sence & 5'-ATG-CTC-TAC-AAC-CCC-ACC-AC-3' & \multirow{2}{*}{$60^{\circ} \mathrm{C}$} \\
\hline & Anti-sence & 5'-GCC-CTT-CGC-ACT-TCT-TAC-AC-3' & \\
\hline \multirow[b]{2}{*}{ GAPDH } & Sence & 5'-AGG-CTG-TTG-TCA-TAC-TTC-TCA-T-3' & \multirow{2}{*}{$60^{\circ} \mathrm{C}$} \\
\hline & Anti-sence & 5'-GGA-GTC-CAC-TGG-CGT-CTT-3' & \\
\hline
\end{tabular}

DNA contamination, as assessed by RT-PCR analysis and his purification was determined by the absorbance ratios $\mathrm{A}_{260} /$ $A_{280}$. The amount of isolated RNA was quantified by measuring its absorbance at $260 \mathrm{~nm}\left(1 \mathrm{~A}_{260}\right.$ unit $\left.=40 \mu \mathrm{g} / \mathrm{mL} \mathrm{RNA}\right)$. Total RNA was reverse transcripted with PrimeScript ${ }^{\mathrm{TM}}$ first strand cDNA synthesis kit, Takara (Takara Bio Inc., Japan).

\section{End point and RT-PCR analysis}

For end point PCR analysis, the KAPA Taq ReadyMix DNA Polymerase (KAPABIOSYSTEMS) method was used. Afterward, cDNA sequences were semi-quantitatively measured using glyceraldehyde-3-phosphate dehydrogenase (GAPDH) as the "housekeeping" gene. All amplification products were separated by electrophoresis in a $1.5 \%$ agarose gel containing Gelred ${ }^{\mathrm{TM}}$ Nucleic Acid Gel Stain (Biotium). Bands were visualized with a UV lamp and gels were photographed with a charge-coupled device (CCD) camera. For a semi-quantitative analysis, gene expression was determined as the relative fluorescence obtained for each molecule compared with the reference gene (GAPDH). Image analysis was performed using the program UVIpro (UVITec). RT-PCR was performed in a $20 \mu \mathrm{L}$ mixture consisting of $10 \mu \mathrm{L}$ KAPA SYBR FAST Master Mix $(2 \times)$ Universal (KAPABIOSYSTEMS), containing Taq DNA polymerase, oligonucleotide primers $(0,2 \mu \mathrm{M}$ each), and $1 \mu \mathrm{M}$ of template cDNA. The amplification consisted of a two-step procedure denaturation at $95^{\circ} \mathrm{C}$ for $3 \mathrm{~min}$ and 40 cycles with denaturation at $95^{\circ} \mathrm{C}$ for $3 \mathrm{sec}$ and then annealing/elongation at $60^{\circ} \mathrm{C}$ for $20 \mathrm{sec}$ using Rotor Gene Q (Giagen, USA). GAPDH was used as an endogenous control. All reactions were performed in triplicates and a standard curve was always included for each pair of primers for assay validation. In addition, a melting curve analysis was performed for detecting the SYBR Green-based objective amplicon. The relative abundance of mRNA of the gene of interest was deducted from the cycle number at which fluorescence increased above background level (Ct) in the exponential phase of the PCR, after normalization to the $\mathrm{Ct}$ of the calibrator. The sequence of primers as well as all their product characteristics and information are shown in Table 1.

\section{Determination of proteasome activity in cell monolayers}

Cells were washed twice in phosphate-buffered saline and then lysated with a solution of $1 \mathrm{mM}$ DTT in water for $1 \mathrm{~h}$ at $4^{\circ} \mathrm{C}(500 \mu \mathrm{l} /$ well of a 6 -well plate $)$ [35]. Lysates were centrifuged at $14,000 \mathrm{~g}$ for $30 \mathrm{~min}$ at $4^{\circ} \mathrm{C}$ to remove non-lysated cells, membranes, and nuclei, and protein concentrations were determined in supernatants by the method of Bradford [36] using bovine serum albumin as standard. Then the supernatants were assayed for the main chymotrypsin-like activity of $20 \mathrm{~S}$ proteasome using the fluorogenic substrate N-Succinyl-Leu-Leu-Val-Tyr-AMC (Succ-LLVY-AMC; SigmaAldrich, Dorset, UK), as previously described [37]. Cell lysates $(50 \mu \mathrm{l})$ were incubated with the fluorogenic substrate (dissolved in DMSO) at final concentration $20 \mu \mathrm{M}$ in $50 \mathrm{mM}$ HEPES, $20 \mathrm{mM} \mathrm{KCl,} 5 \mathrm{mM} \mathrm{MgCl}$, 1 mM DTT pH 7.8 buffer, in a total volume of $100 \mu \mathrm{l}$, for $1 \mathrm{~h}$ at $37^{\circ} \mathrm{C}$. To determine the specific degradation of Succ-LLVY-AMC by proteasome, MG132, a proteasome inhibitor, at final concentration $200 \mu \mathrm{M}$, was added. The reaction was stopped by addition of $100 \mathrm{mM}$ sodium acetate buffer $\mathrm{pH} 4.3(150 \mu \mathrm{l})$. Fluorescence signal for AMC was monitored at $370 \mathrm{~nm}$ excitation and $440 \mathrm{~nm}$ emission in a TECAN infinite M200 (Austria) fluorometer, using free AMC as a standard. Proteasome activity was expressed as pmole $\mathrm{AMC} / \mu \mathrm{g}$ total protein.

\section{Cell proliferation}

To determine whether these agents affect the proliferation of DLD-1 colon cancer cell line, the water-soluble tetrazolium 
salt (WST-1) assay was used. The assay is based on the reduction of WST-1 by viable cells, producing a soluble formazan salt. DLD- 1 cells $\left(6 \times 10^{3}\right.$ per well $)$ were plated in $100 \mu \mathrm{L}$ cell culture medium with $10 \%$ FBS in a 96-well plate. After $24 \mathrm{~h}$ of plating, cells were washed twice with fresh culture medium serum free. Before the addition of EGF $(20 \mathrm{ng} /$ $\mathrm{mL}$ ), cells were incubated with the specific inhibitors of EGFR (AG1478) and HER2 (CP-724,714), alone or in combination for $30 \mathrm{~min}$. After pre-incubation of the inhibitors, EGF was added to the culture medium for $24 \mathrm{~h}$ and $48 \mathrm{~h}$ incubation time. Cell proliferation was determined using a microplate reader Infinite 200 (Tecan Austria Gmbtl). The absorbance was measured at a wavelength of $440 \mathrm{~nm}$ and a reference wavelength of $650 \mathrm{~nm}$.

\section{Statistical analysis}

The statistical analysis of the results assessed with 'unpaired $t$-test' or 'test ANOVA' Origin 6.0 (Microcal Software Inc., USA). All values are given as mean \pm standard deviation of three separate experiments in triplicate.

\section{RESULTS}

\section{EGF/EGFR is the main signaling axis for the EGFR gene expression}

EGFR is a vital receptor in colon cancer and a significant regulator of gene expression. Therefore, we first evaluated the impact of EGF on gene expression of EGFR. For this purpose, two specific TKIs were used: AG1478 against EGFR and CP-724,714 against HER2. Colon cancer cells after starvation in serum-free medium for $24 \mathrm{~h}$ were pre-incubated with the inhibitors $(1 \mu \mathrm{M})$ for 30 min followed by further incubation with EGF $(20 \mathrm{ng} / \mathrm{mL})$ for $24 \mathrm{~h}$. The mRNA levels of EGFR were assessed by RT-PCR analysis as described in the materials and methods section. As shown in Figure 1, EGF significantly upregulated the expression of EGFR. In addition, the inhibition of EGFR activation by AG1478 abolished the EGF induction by restoring the mRNA levels of the receptor lower to that of the control cells. On the other hand, the inhibition of HER2 activation by CP-724,714 in the presence of EGF elevated the EGFR expression. Moreover, the combined inhibition of both receptors' activity strongly decreased the levels of EGFR, reaching the levels obtained when the EGFR inhibitor AG1478 was used alone. The above data highlight that the EGF/EGFR-mediated effect of EGF is the crucial axis for the gene expression of EGFR in DLD-1 colon cancer cells.

\section{The effect of EGF/EGFR on proliferation rate of DLD-1 colon cancer cells}

It is known that EGFR regulates several cellular processes in colon cancer such as survival, differentiation, and proliferation. Taking into account that EGF affects EGFR expression, we further examined whether EGF could affect the

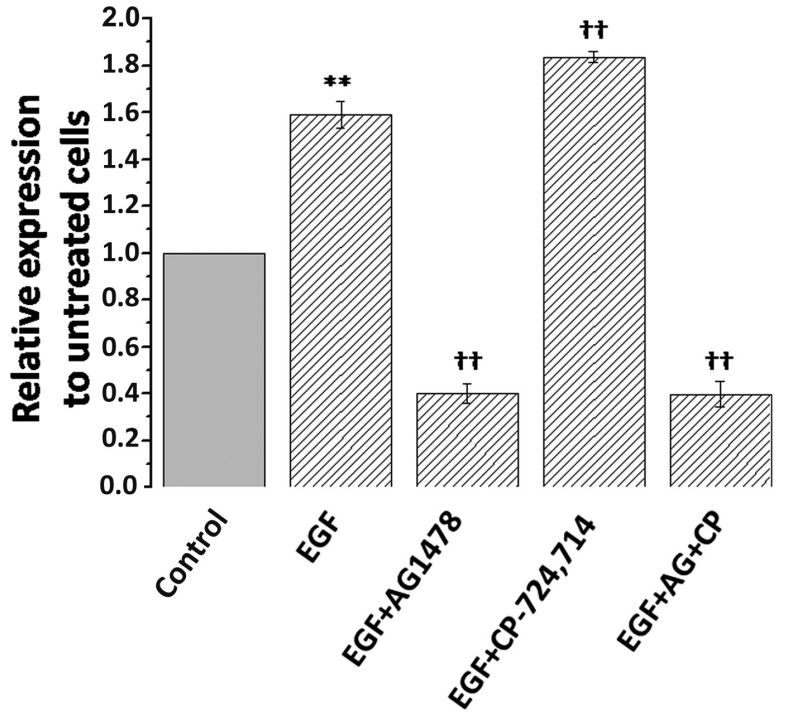

Figure 1. The effect of EGF on gene expression of EGFR in DLD-1 colon cancer cells.

Note: The mRNA levels were assessed by RT-PCR analysis. Cancer cells first pre-incubated with AG1478 $(1 \mu \mathrm{M})$ and CP-724,714 (1 $\mu \mathrm{M})$ for $30 \mathrm{~min}$, followed by the introduction of EGF $(20 \mathrm{ng} / \mathrm{mL})$. Total incubation time was $24 \mathrm{~h}$. Results are expressed as relative expression and normalized to untreated cells. Statistically significant differences compared with control or EGF-treated cells are symbolized with ${ }^{* *}(p<0.01)$ or $\dagger \dagger(p<0.01)$, respectively.

proliferation of DLD-1 cells. As shown in Figure 2, EGF had no effect on cell proliferation. Moreover, the inhibition of the receptors alone and in combination has no regulatory effect on the proliferation of DLD-1 cell, following either $24 \mathrm{~h}$ or 48 $\mathrm{h}$ incubation periods (Figure 2). These data may well be in accordance with the existence of K-Ras mutation. However, the case that the EGF/EGFR signaling axis could affect other intracellular components crucial for cell proliferation and survival could not be excluded; therefore, we forced to evaluate the EGF effect on proteasome expression and activity.

\section{The effect of EGF/EGFR on proteasome subunits' gene expression}

Taking into consideration the above data, we then investigated the impact of EGF and EGF-mediated, EGFR, and/or HER2 inhibition on gene expression of the catalytic proteasome subunits. The proteasome subunits expression was assessed by end point PCR, as described in the materials and methods section. It is noticing that the results obtained for the expression of the three proteasome subunits exhibited a similar pattern. As shown in Figure 3, despite the presence of $\mathrm{K}$-Ras mutation, EGF significantly increases the expression of $\beta 5, \beta 1$ and $\beta 2$ proteasome subunits, indicating that the action 

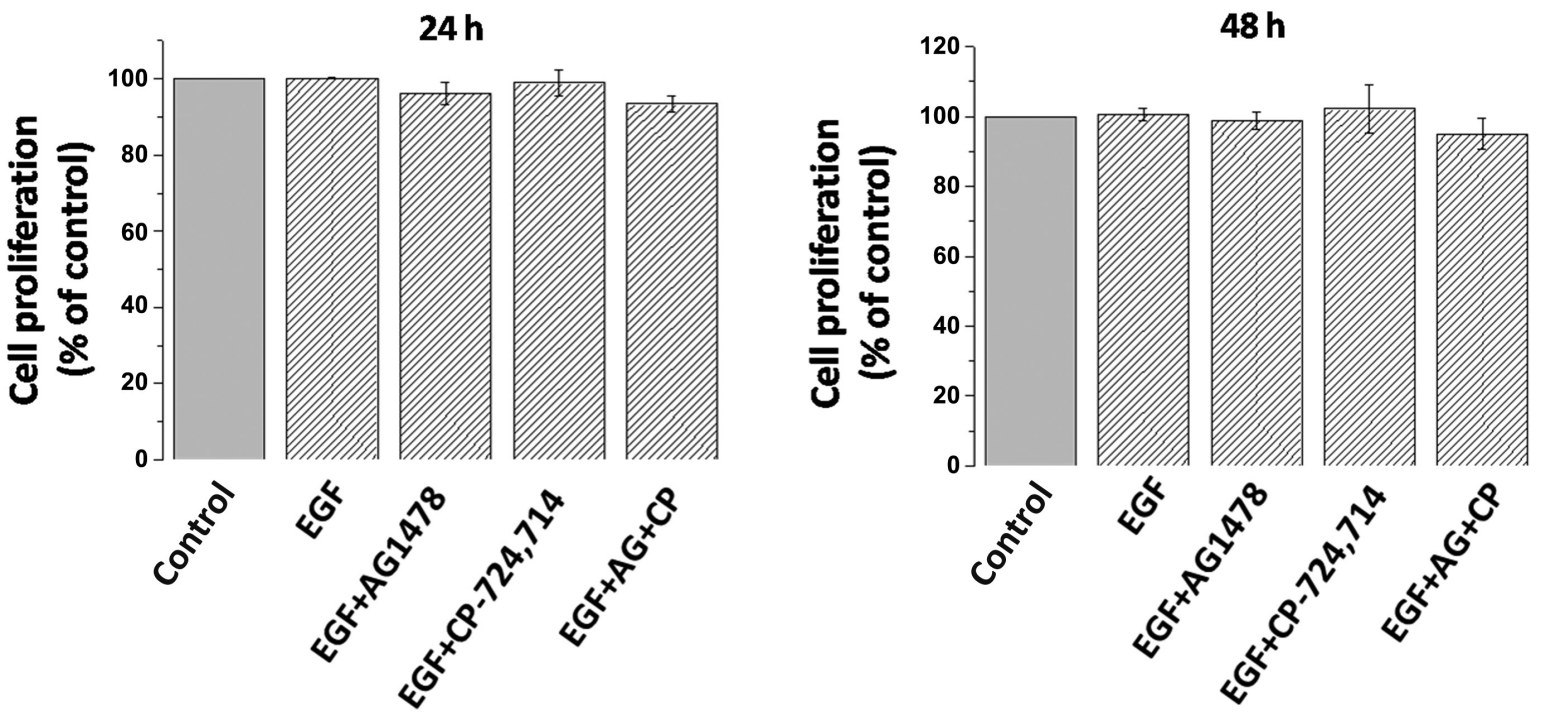

Figure 2. The effect of EGFR and/or HER2 inhibition on DLD-1 proliferation.

Note: Cells were incubated with AG1478 $(1 \mu \mathrm{M})$ and CP-724,714 $(1 \mu \mathrm{M})$ for $30 \mathrm{~min}$, followed by the introduction of EGF (20 $\mathrm{ng} / \mathrm{mL})$. Cell proliferation was evaluated for $24 \mathrm{~h}$ and $48 \mathrm{~h}$. The results are expressed as mean \pm SD of three separate experiments in triplicate.
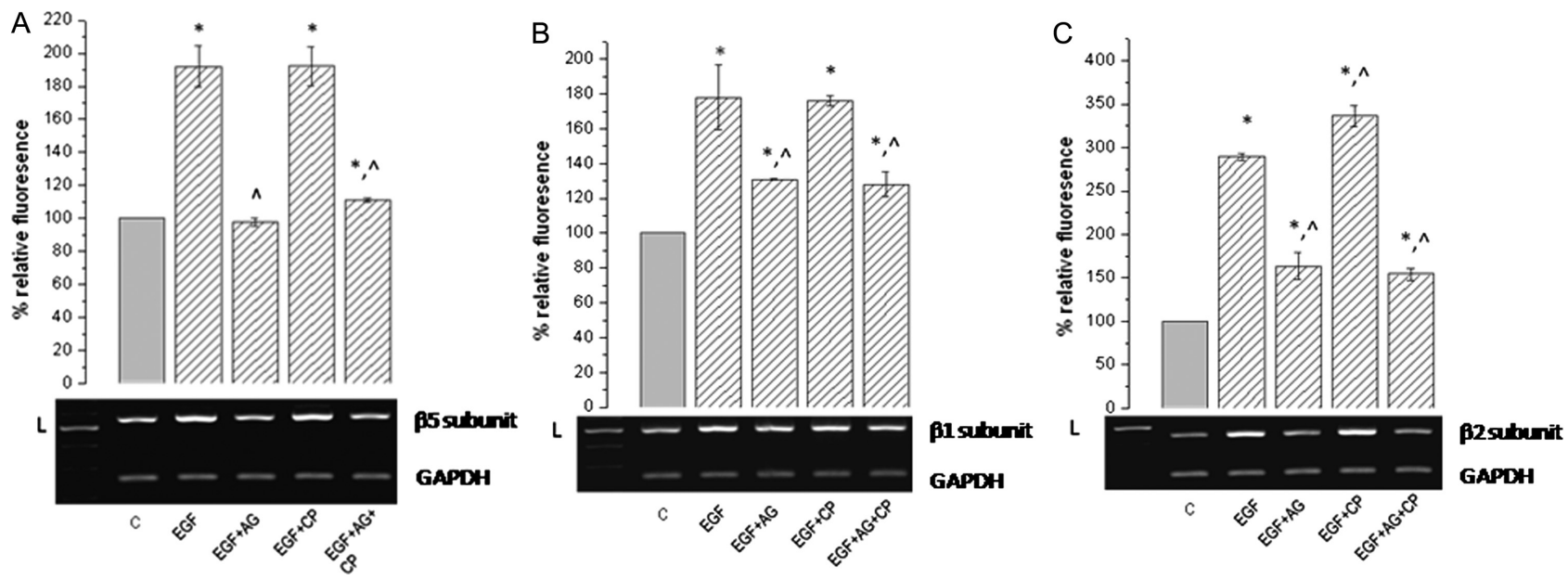

Figure 3. The effect of EGF on gene expression of (A) $\beta 5$, (B) $\beta 1$, and (C) $\beta 2$ catalytic proteasome subunits, respectively, in DLD-1 colon cancer cell line.

Note: The mRNA levels are assessed by end point PCR analysis. Cancer cells incubated with AG1478 $(1 \mu \mathrm{M})$ and CP-724,714 (1 $\mu \mathrm{M})$ for $30 \mathrm{~min}$, followed by the introduction of EGF $(20 \mathrm{ng} / \mathrm{mL})$. Total incubation time was $24 \mathrm{~h}$. The \% relative fluorescence of the gene of interest/the reference gene (GAPDH) is given in all diagrams. Statistically significant differences compared with control or EGF-treated cells are symbolized with ${ }^{*}(p<0.05)$ or ${ }^{\wedge}(p<0.05)$, respectively. All treatments are given as abbreviations. C: control cells; EGF: epidermal growth factor $(20 \mathrm{ng} / \mathrm{mL})$; AG: AG-1487 EGFR inhibitor $(1 \mu \mathrm{M})$; CP: CP-724,714 HER2 inhibitor $(1 \mu \mathrm{M})$.

of EGF overwhelms the effect of K-Ras mutation in order to induce proteasome expression. Following treatment with EGF and blocking either EGFR or both EGFR and HER2 activities, the EGF-stimulatory effects were significantly reduced. Moreover, blocking of HER2 activity alone does not suppress the EGF-enhanced expression of proteasome subunits. These data clearly show that, despite the presence of K-Ras mutation, EGF sensitizes its own receptor in order to significantly regulate gene expression of all three proteasome catalytic subunits. Interestingly, the expression patterns of proteasome and EGFR are very similar, indicating a possible correlation between them. 


\section{The effect of EGF/EGFR on $\beta 5$ catalytic proteasome activity}

Similar to gene expression, we evaluated the impact of EGF on the activity of the $\beta 5$ catalytic proteasome subunit. For that reason, we used the same specific TKIs as described earlier, and total incubation time was $48 \mathrm{~h}$. The activity of $\beta 5$ (chymothrypsin-like) catalytic proteasome subunit was determined using the fluorogenic substrate N-Succinyl-Leu-LeuVal-Tyr-7-Amido-4-Methylcoumarin, as described in the materials and methods section. Interestingly, the activity levels of $\beta 5$ proteasome subunit (Figure 4) share a similar pattern with the expression levels of the subunit (Figure 3A). Particularly, EGF significantly increases the $\beta 5$ proteasome subunit activity levels, despite the presence of K-Ras mutation. Moreover, after stimulation with EGF, the inhibition of HER2 activity does not change the EGF-mediated effect, whereas the blocking of EGFR activity or of both EGFR/HER2 abolished the stimulatory effect of EGF. According to the results, it is suggested that EGF significantly regulates the activity of the $\beta 5$ proteasome subunit via the EGFR, without HER2 involvement.

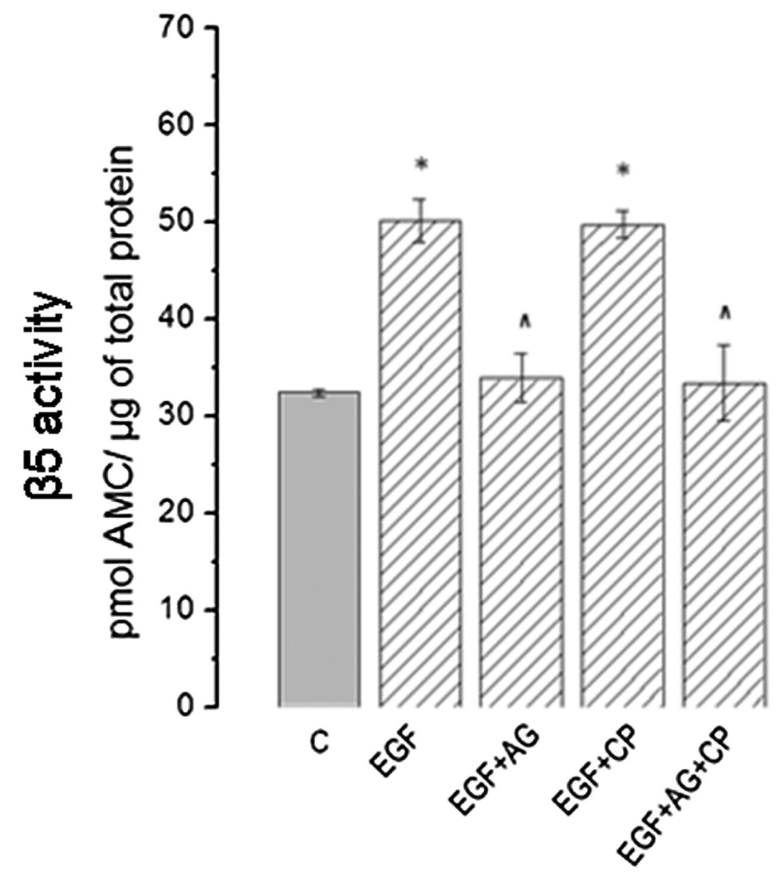

Figure 4. The effect of EGF on the activity of the $\beta 5$ catalytic proteasome subunit in DLD-1 colon cancer cells. The activity levels were determined using the fluoregenic substrate SucLLVY-AMC. Note: Colon cancer cells first pre-incubated with AG1478 $(1 \mu \mathrm{M})$ and CP-724,714 $(1 \mu \mathrm{M})$ for $30 \mathrm{~min}$, followed by the introduction of EGF $(20 \mathrm{ng} / \mathrm{mL})$. Total incubation time was $48 \mathrm{~h}$. The pmol of hydrolyzed $\mathrm{AMC} /$ the $\mathrm{mg}$ of total protein is presented in all diagram. Statistically significant differences compared with control or EGF-treated cells are symbolized with $*(p<0.05)$ or ${ }^{\wedge}(p<$ $0.05)$, respectively.

\section{Activation of Nrf2 does not affect the gene expression of proteasome subunits}

Since it was known that EGF induces the activation of Nrf2 [38], and in turn the activation of Nrf2 induces, in some cases, proteasome expression [25], we examined the impact of the activation of Nrf2 on gene expression of the catalytic proteasome subunits in DLD-1 colon cancer cell lines. For this experiment, the Oltipraz, a synthetic activator of Nrf2, was used. Colon cancer cells were incubated with Oltipraz $(30$ $\mu \mathrm{M}$ ) for $24 \mathrm{~h}$ and then the proteasome subunits gene expression was determined by end point PCR analysis, as described in the materials and methods section. As shown in Figure 5, the Oltipraz did not exhibit any significant effect on gene expression of all three catalytic proteasome subunits, indicating that in DLD-1 colon cancer cells the EGF-mediatedinduced proteasome expression is not depended on the Nrf2 activation.

\section{DISCUSSION}

Several in vivo and in vitro studies relate the importance of EGFR in colon cancer development and progression. Through its pathways, EGFR is able to regulate vital cellular processes as proliferation, survival, and metastasis. Moreover, EGFR is responsible for the expression of several molecules which contribute to cancer promotion. The inhibition of EGFR results in antitumor effects both in vivo and in vitro. A very common co-receptor for EGFR is HER2. In colon cancer, the combined EGFR/HER2 activity inhibition enhances the anticancer effect, indicating interplay between those two receptors. Moreover, K-Ras is a very important signaling molecule downstream of EGFR and HER2, which is often mutated in colon cancer. The existence of K-Ras mutations induces carcinogenesis and demonstrates resistance against anti-EGFR therapies. The ubiquitin-proteasome system is the main regulator of the non-lysosomatic degradation of a variety of intracellular proteins. Several studies highlight the significance of the proteasome in several types of cancer since proteasome inhibition induces apoptosis of cancer cells. Proteasome affects the protein levels of EGFR and its phosporylation, in several types of cancer including colon [39-42]. This indicates a correlation between EGFR and proteasome. In one study, proteasome inhibition affected some signaling molecules downstream of EGFR, which in turn affected Nrf2 activation, also implicating the transcription factor in the correlation of EGFR and proteasome [43]. Thus, it has been demonstrated that proteasome is able to modulate EGFR; however, it is not known whether the reverse option is possible. Taking into consideration previous studies showing that EGF appears to regulate the survival time of Caenorhabditis elegans by activating proteasome [44] and that EGF increases proteasome expression through activation of EGFR in prostate cancer cells [45], our basic goal was to evaluate the effect of EGF/EGFR and then HER2 on the expression and the activity of the catalytic proteasome subunits. It is worth mentioning that in DLD-1 cancer cells, the introduction of exogenous EGF leads 
A

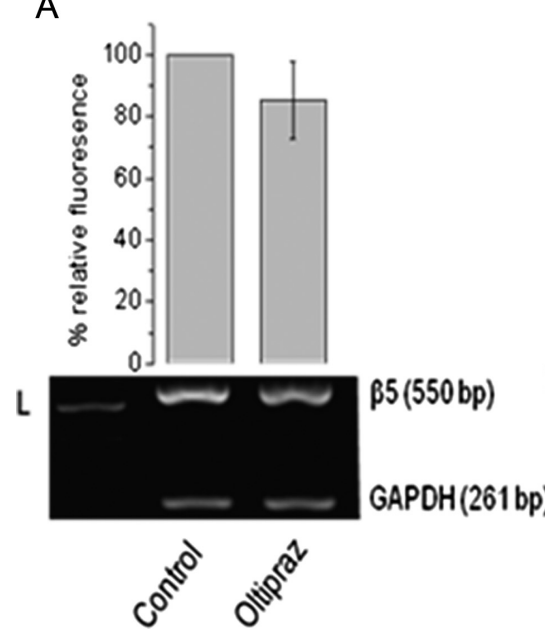

B

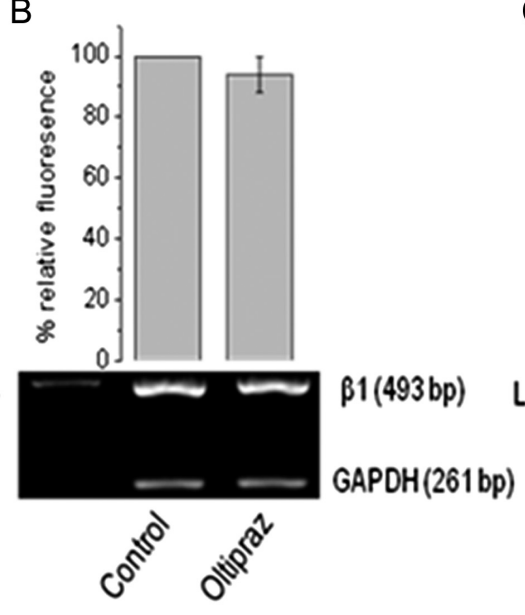

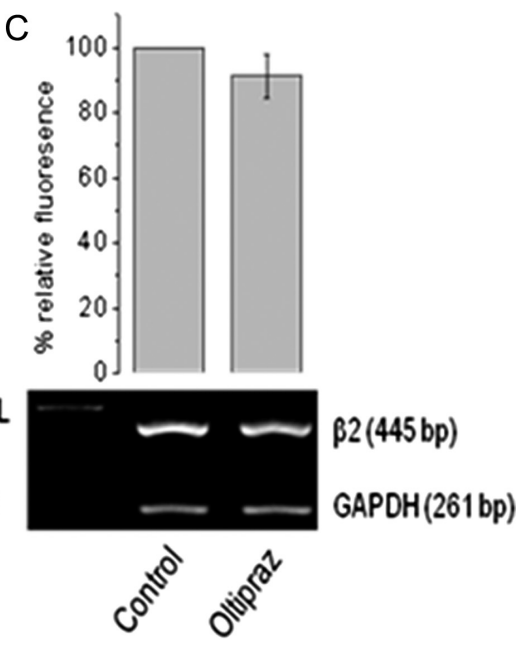

Figure 5. The effect of the activation of $\mathrm{Nrf2}$ on gene expression of (A) $\beta 5$, (B) $\beta 1$, and (C) $\beta 2$ catalytic proteasome subunits in DLD-1 colon cancer cells.

Note: The mRNA levels are assessed by end point PCR analysis. Cancer cells incubated with Oltipraz (30 $\mu \mathrm{M})$ for $24 \mathrm{~h}$.

to phosphorylation of EGFR, as previously demonstrated [46]. As shown in Figure 1, EGF also significantly upregulated the expression of EGFR. As previously reported, EGF upregulates the expression of EGFR in breast cancer MDA-MB-231 cells through NF- $\kappa B$ activation [47]. The phosphorylated EGFR activates NF- $\mathrm{BB}$ through PI3-K pathway leading to the phosphorylation of $\mathrm{I} \kappa \mathrm{B} \alpha$ kinase on serine-32 and -36; therefore, promoting the nuclear translocation of NF- $\mathrm{KB}$ in $\mathrm{PC}-3$ prostate cancer cells [48]. This pathway may also be responsible for the observed upregulated expression of EGFR by its ligand EGF. Moreover, it is known that $\mathrm{I} \kappa \mathrm{B} \alpha$ kinase phosphorylates the NF- $\kappa B$ inhibitor $I \kappa B \alpha$, which subsequently is ubiquitinated and degraded by proteasome, leading in the release of transcription factor and its nuclear translocation. Given that EGF/ EGFR signaling axis strongly enhances both the proteasome expression and activity overwhelming the action of KRas mutation (Figures 3 and 4), it may be plausible to suggest that an auto-regulatory mechanism of EGF/EGFR signaling exists in DLD-1 cancer cells. In this regard, it might be that EGF activates EGFR, which in turn enhances the expression and activation of proteasome that then contributes to the activation of NF- $\mathrm{KB}$ pathway which finally mediates the upregulation of EGFR gene expression. It has been reported that the activation of Nrf2 is able to induce proteasome expression [49-51]. Although the involvement of Nrf2 in basal expression of human proteasome genes was hinted by the correlation of increased proteasome gene expression with overexpression of Nrf2 in human colon cancer cells [52], the synthetic activator of Nrf2, Oltipraz, did not exhibit any significant effect on proteasome subunits expression (Figure 5). It may be attributed, however, to K-Ras mutation. As previously proposed, the phosphorylation of Nrf2 by several kinases including, PKC, MAPK, and PI3K/Akt may affect the activation of this transcription factor and subsequently the regulation of
Antioxidant Response Elements (ARE)-responsive genes. These upstream kinases for Nrf2 phosphorylation are the downstream of EGFR pathway and, in particular, downstream of activated Ras in EGFR pathway [53, 54]. Consequently, in K-Ras-mutated DLD-1 cells, it is expected Nrf2 to be already activated and thus the Oltipraz does not exhibit any effect. However, the observed enhancement of proteasome expression and activity by EGF may suggest that an additional or exclusive pathway is implicated in this process. As previously reported [45], EGF increases proteasome expression, almost exclusively through JAK-STAT3 signaling pathway in prostate cancer cells, while the MAPK and PI3K signaling pathways do not actually get involved in that process. This could also be a possible scenario in DLD-1 cells and could partly explain the fact that despite the presence of K-Ras mutation, EGF significantly regulates proteasome expression and activity. Several reports have suggested that Nrf2 mediates feedback induction of proteasome genes in mammalian cells when the proteasome activity is compromised [55,56], and also it plays an important role in upregulating proteasome genes in response to oxidative stress $[51,57]$. Nrf2 is not the sole transcription factor responsible for basal expression of human proteasome genes. It has been demonstrated that the CCAAT box-binding transcription factor NF-Y binds promoters of a large set of human proteasome genes that carries the CCAAT box [58]. Some proteasome genes may be regulated by other transcription factors in addition to Nrf2 and NF-Y. It was suggested that the heat shock factor 2 (HSF2) may play a role in regulating basal transcription of mouse proteasome genes [59]. It is known that both enhanced proteasome and EGFR activation contribute to increased tumor survival, while proteasome and EGFR inhibitions result in apoptosis in several types of cancer including colon $[10,23,24]$. Therefore, it is plausible to suggest that EGF enhances cancer cells survival through the 


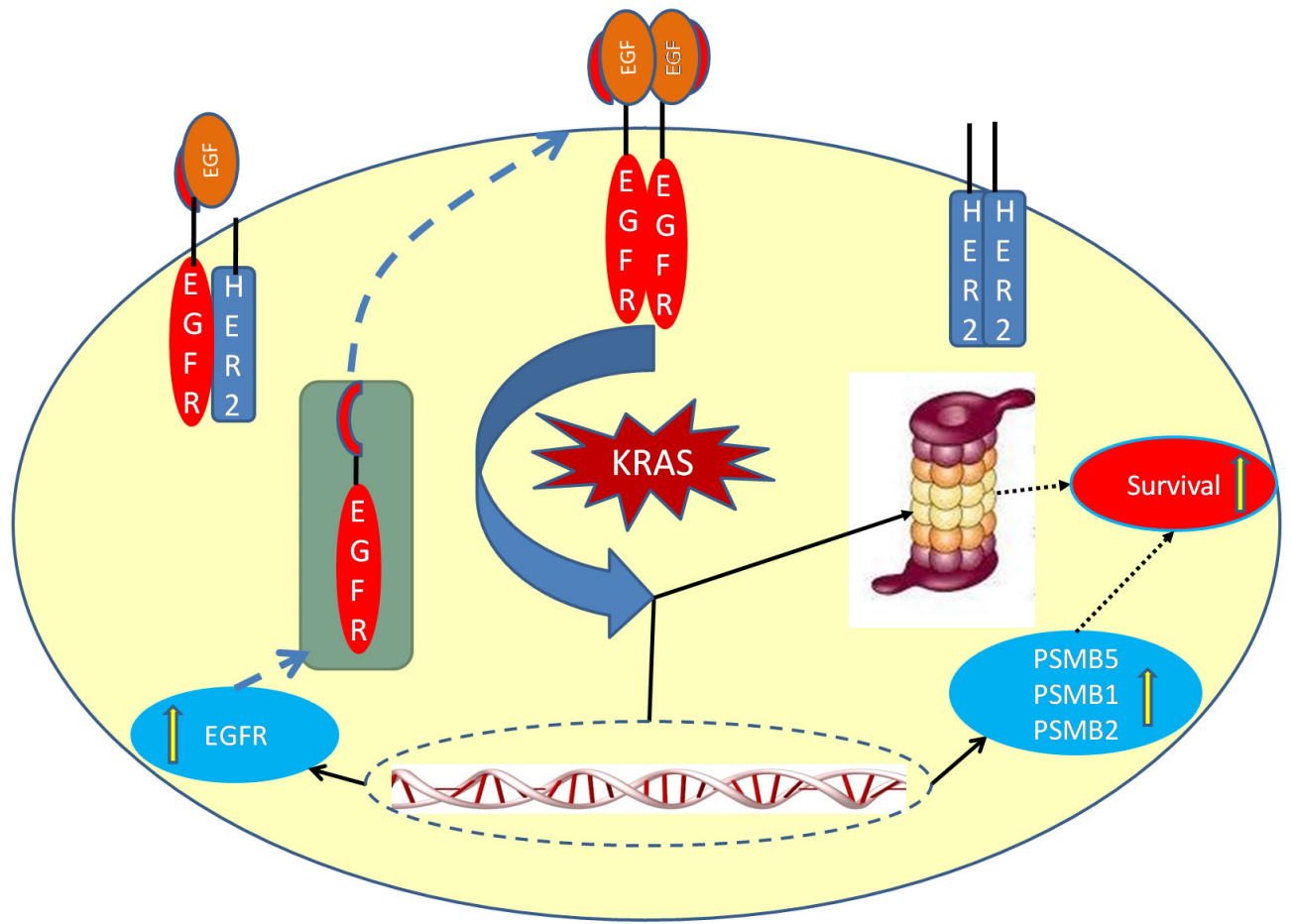

Figure 6. Schematic representation showing that the EGF/EGFR signaling axis overwhelms the action of K-Ras mutation and significantly enhances proteasome expression and activity possibly contributing to cancer cells survival.

Note: Taking into consideration that the activation of EGFR by EGF which enhances the expression and activation of proteasome thus contributing in the activation of NF-KB pathway which finally mediates the upregulation of EGFR gene expression, it may be plausible to speculate that an auto-regulatory mechanism of EGF/EGFR signaling exists in DLD-1 cancer cells.

activation of proteasome, whereas the inhibition of EGFR may partly cause apoptosis due to proteasome inhibition. This may explain that the combined EGFR/proteasome inhibition results in enhanced antitumor effect $[31,32,34]$. In addition, the proteasome may regulate the EGF/EGFR pathway by contribution in degradation of EGFR by lysosomes, as previously reported [60]. According to the significance of EGFR in colon cancer, we evaluated the action of EGF on the expression of its own receptor and the proliferation of DLD-1 cells. Our data suggest that EGF/EGFR signaling axis is the main mediator for the expression of the receptor. Interestingly, the expression patterns of proteasome and EGFR were very similar. On the other hand, although EGFR is a vital receptor for colon cancer cells, the proliferation rates of DLD-1 cells were not affected by EGF/EGFR system, possibly due to existence of K-Ras mutation. In summary, we report that EGF/EGFR signaling axis significantly regulates the expression and the activity of the catalytic proteasome subunits in DLD-1 colon cancer cells, overwhelming the action of K-Ras mutation. Moreover, EGF/EGFR signaling axis regulates the EGFR expression in a similar mode that regulates proteasome, indicating an EGFR/proteasome correlation. The conclusions are summarized in Figure 6. These data provide the basis for more studies, which will declare the pathway(s) that EGF enhances EGFR expression and activated EGFR regulates proteasome expression, and how this could contribute to the development of more effective anticancer approaches targeting on EGFR and proteasome in colon cancer.

\section{ACKNOWLEDGMENTS}

This research has been co-financed by the European Union (European Social Fund - ESF) and Greek national funds through the Operational Program "Education and Lifelong Learning" of the National Strategic Reference Framework (NSRF) - Research Funding Program: Heracleitus II. Investing in knowledge society through the European Social Fund.

\section{REFERENCES}

[1] Ferlay J, Autier P, Boniol M, Heanue M, Colombet M, Boyle P. Estimates of the cancer incidence and mortality in Europe in 2006. Ann Oncol. 2007;18:581-92.

[2] Centers for Disease Control and Prevention: United States Cancer Statistics: US Cancer Statistics Working Group, 19992010. Cancer Incidence and Mortality Data, www.apps.nccd. gov/uscs.

[3] Mitsudomi T, Yatabe Y. Epidermal growth factor receptor in relation to tumor development: EGFR gene and cancer. FEBS J. 2010;277:301-8.

[4] Tsonis AI, Afratis N, Gialeli C, Ellina MI, Piperigkou Z, Skandalis SS, Theocharis AD, Tzanakakis GN, Karamanos NK. Evaluation of 
the coordinated actions of estrogen receptors with epidermal growth factor receptor and insulin-like growth factor receptor in the expression of cell surface heparan sulfate proteoglycans and cell motility in breast cancer cells. FEBS J. 2013;280: 2248-59.

[5] Chrisostomi G, AD Theocharis, NK Karamanos. Roles of matrix metalloproteinases in cancer progression and their pharmacological targeting. Febs J. 2011;278:16-27.

[6] Theocharis AD, Skandalis SS, Tzanakakis GN, Karamanos NK. Proteoglycans in health and disease: novel roles for proteoglycans in malignancy and their pharmacological targeting. FEBS J. 2010;277(19):3904-23.

[7] Schneider MR, Wolf E. The epidermal growth factor receptor ligands at a glance. J Cell Physiol. 2009;218:460-6.

[8] Zhang X, Gureasko J, Shen K, Cole PA, Kuriyan J. An allosteric mechanism for activation of the kinase domain of epidermal growth factor receptor. Cell. 2006;125:1137-49.

[9] Graus-Porta D, Beerli RR, Daly JM, Hynes NE. ErbB-2, the preferred heterodimerization partner of all ErbB receptors, is a mediator of lateral signaling. EMBO J. 1997;16:1647-55.

[10] Gross ME, Zorbas MA, Danels YJ, Garcia R, Gallick GE, Olive M, Brattain MG, Boman BM, Yeoman LC. Cellular growth response to epidermal growth factor in colon carcinoma cells with an amplified epidermal growth factor receptor derived from a familial adenomatous polyposis patient. Cancer Res. 1991; 51:1452-9.

[11] Pohl M, Stricker I, Schoeneck A, Schulmann K, Klein-Scory S, Schwarte-Waldhoff I, Hasmann M, Tannapfel A, Schmiegel W, Reinacher-Schick A. Antitumor activity of the HER2 dimerization inhibitor pertuzumab on human colon cancer cells in vitro and in vivo. J Cancer Res Clin Oncol. 2009;135:1377-86.

[12] Bos JL, Fearon ER, Hamilton SR, Verlaan-de Vries M, van Boom $\mathrm{JH}$, van der Eb AJ, Vogelstein B. Prevalence of Ras mutations in human colorectal cancers. Nature. 1987;327:293-7.

[13] Finkelstein SD, Sayegh R, Christensen S, Swalsky PA. Genotypic classification of colorectal adenocarcinoma. Biologic behavior correlates with K-ras-2 mutation type. Cancer. 1993;71:3827-38.

[14] Boughdady IS, Kinsella AR, Haboubi NY, Schofield PF. K-ras gene mutations in adenomas and carcinomas of the colon. Surg Oncol. 1992;1:275-82.

[15] Amando RG, Wolf M, Peeters M, Van Cutsem E, Siena S, Freeman DJ, Juan T, Sikorski R, Suggs S, Radinsky R, Patterson $\mathrm{SD}$, Chang DD. Wild-type KRAS is required for panitumumab efficacy in patients with metastatic colorectal cancer. J Clin Oncol. 2008;26:1626-34.

[16] de Roock W, Piessevaux H, de Schutter J, et al., KRAS wild-type state predicts survival and is associated to early radiological response in metastatic colorectal cancer treated with cetuximab. Annal Oncol. 2008;19:508-15.

[17] Di Fiore F, Blanchard F, Charbonnier F, Le Pessot F, Lamy A, Galais MP, Bastit L, Killian A, Sesboüé R, Tuech JJ, Queuniet AM, Paillot B, Sabourin JC, Michot F, Michel P, Frebourg T. Clinical relevance of KRAS mutation detection in metastatic colorectal cancer treated by Cetuximab plus chemotherapy. Bri J Canc. 2007;96:1166-9.

[18] Lièvre A, Bachet JB, Boige V, Cayre A, Le Corre D, Buc E, Ychou M, Bouché O, Landi B, Louvet C, André T, Bibeau F, Diebold MD, Rougier P, Ducreux M, Tomasic G, Emile JF, Penault-Llorca F, Laurent-Puig P. KRAS mutations as an independent prognostic factor in patients with advanced colorectal cancer treated with cetuximab. J Clin Oncol. 2008;26:374-9.

[19] Karapetis CS, Khambata-Ford S, Jonker DJ, O'Callaghan CJ, Tu D, Tebbutt NC, Simes RJ, Chalchal H, Shapiro JD, Robitaille S, Price TJ, Shepherd L, Au HJ, Langer C, Moore MJ, Zalcberg JR. K-ras mutations and benefit from cetuximab in advanced colorectal cancer. New England J Med. 2008;359:1757-65.

[20] Groll M, Ditzel L, Löwe J, Stock D, Bochtler M, Bartunik HD, Huber R. Structure of $20 \mathrm{~S}$ proteasome from yeast at a $2.4 \mathrm{~A}$ resolution. Nature. 1997;386:463-71.

[21] Kisselev AF, Callard A, Goldberg AL. Importance of the different proteolytic sites of the proteasome and the efficacy of inhibitors varies with the protein substrate. J Biol Chem. 2006;281: 8582-90.

[22] Chondrogianni N, Gonos ES. Proteasome activation as a novle antiaging strategy. IUBMB Life. 2008;60(10):651-5.

[23] Ogiso Y, Tomida A, Lei S, Omura S, Tsuruo T. Proteasome inhibition circumvents solid tumor resistance to topoisomerase IIdirected drugs. Cancer Res. 2000;60:2429-34.

[24] Minami T, Adachi M, Kawamura R, Zhang Y, Shinomura Y, Imai K. Sulindac enhances the proteasome inhibitor bortezomibmediated oxidative stress and anticancer activity. Clin Cancer Res. 2005;11:5248-56.

[25] Lee CS, Ho DV, Chan JY. Nuclear factor-erythroid 2-related factor 1 regulates expression of proteasome genes in hepatocytes and protects against endoplasmic reticulum stress and steatosis in mice. FEBS J. 2013;280:3609-20.

[26] Padmanabhan B, Tong KI, Ohta T, Nakamura Y, Scharlock M, Ohtsuji M, Kang MI, Kobayashi A, Yokoyama S, Yamamoto M. Structural basis for defects of Keap1 activity provoked by its point mutationsin lung cancer. Mol Cell. 2006;21:689700.

[27] Singh A, Misra V, Thimmulappa RK, Lee H, Ames S, Hoque MO, Herman JG, Baylin SB, Sidransky D, Gabrielson E, Brock MV Biswal S. Dysfunctional KEAP1-NRF2 interaction in non-smallcell lung cancer. PLoS Med. 2006;3:420.

[28] Kim YJ, Ahn JY, Liang P, Ip C, Zhang Y, Park YM. Human prx1 gene is a target of Nrf2 and is up-regulated by hypoxia/ reoxygenation: implication to tumor biology. Cancer Res. 2007; 67:546-54.

[29] Wang XJ, Sun Z, Villeneuve NF, Zhang S, Zhao F, Li Y, Chen W, Yi $\mathrm{X}$, Zheng W, Wondrak GT, Wong PK, Zhang DD. Nrf2 enhances resistance of cancer cells to chemotherapeutic drugs, the dark side of Nrf2. Carcinogenesis. 2008;29:1235-43.

[30] Tarumoto $T$, Nagai $T$, Ohmine $K$, Miyoshi $T$, Nakamura $M$, Kondo T, Mitsugi K, Nakano S, Muroi K, Komatsu N, Ozawa K. Ascorbic acid restores sensitivity to imatinib via suppression of Nrf2-dependent gene expression in the imatinib-resistant cell line. Exp Hematol. 2004;32:375-81.

[31] Lorch JH, Thomas TO, Schmoll HJ. Bortezomib inhibits cell-cell adhesion and cell migration and enhances epidermal growth factor receptor inhibitor-induced cell death in squamous cell cancer. Cancer Res. 2007;67:727-34.

[32] Cascone T, Morelli MP, Morgillo F, Kim WY, Rodolico G, Pepe S, Tortora G, Berrino L, Lee HY, Heymach JV, Ciardiello F. Synergistic anti-proliferative and pro-apoptotic activity of combined therapy with bortezomib, a proteasome inhibitor, with anti-epidermal growth factor receptor (EGFR) drugs in human cancer cells. J Cell Physiol. 2008;216:698-707.

[33] Sloss CM, Wang F, Liu R, Xia L, Houston M, Ljungman D, Palladino MA, Cusack JC Jr. Proteasome inhibition activates EGFR and EGFR-independent mitogenic kinase signaling pathways in pancreatic cancer cells: Implications for combination therapy. Clin Cancer Res. 2008;14:5116-23.

[34] An J, Rettig MB. Epidermal growth factor receptor inhibition sensitizes renal cellcarcinoma cells to the cytotoxic effects of bortezomib. Mol Cancer Ther. 2007;6:61-9.

[35] Caballero M, Liton PB, Epstein DL, Gonzalez P. Proteasome inhibition by chronic oxidative stress in human trabecular 
meshwork cells. Biochem Biophys Res Commun. 2003;308(2): 346-52.

[36] Bradford MM. A rapid and sensitive method for the quantitation of microgram quantities of protein utilizing the principle of protein-dye binding. Anal Biochem. 1976;72:248-54.

[37] Reinheckel T, Ullrich O, Sitte N, Grune T. Differential impairment of $20 \mathrm{~S}$ and $26 \mathrm{~S}$ proteasome activities in human hematopoietic K562 cells during oxidative stress. Arch Biochem Biophys. 2000;377(1):65-8.

[38] Yamadori T, Ishii Y, Homma S, Morishima Y, Kurishima K, Itoh K, Yamamoto M, Minami Y, Noguchi M, Hizawa N. Molecular mechanisms for the regulation of Nrf2-mediated cell proliferation in non-small-cell lung cancers. Oncogene. 2012:31(45): 4768-77.

[39] Cusack JC Jr, Liu R, Houston M, Abendroth K, Elliott PJ, Adams J, Baldwin AS. Enhanced chemosensitivity to CPT-11 with proteasome inhibitor PS-341: implications for systemic nuclear factor- B inhibition. Cancer Res. 2001;61:3535-40.

[40] Hochwald SN, Lind DS, Malaty J, Copeland EM 3rd, Moldawer LL, MacKay SL. Antineoplastic therapy in colorectal cancer through proteasome inhibition. Am Surg. 2003;69:15-23.

[41] Concannon CG, Koehler BF, Reimertz C, Murphy BM, Bonner C, Thurow N, Ward MW, Villunger A, Strasser A, Kögel D, Prehn $\mathrm{JH}$. Apoptosis induced by proteasome inhibition in cancer cells: predominant role of the p53/PUMA pathway. Oncogene. 2007; 26:1681-92.

[42] Ciardiello F, Caputo R, Bianco R, Damiano V, Pomatico G, De Placido S, Bianco AR, Tortora G. Antitumor effect and potentiation of cytotoxic drugs activity in human cancer cells by ZD1839 (Iressa), an epidermal growth factor receptor-selective tyrosine kinase inhibitor. Clin Cancer Res. 2000;6:2053-63.

[43] Papaiahgari S, Yerrapureddy A, Hassoun PM, Garcia JG, Birukov KG, Reddy SP. EGFR-activated signaling and actin remodeling regulate cyclic stretch-Induced NRF2-ARE activation. Am J Respir Cell Mol Biol. 2007;36:304-12.

[44] Liu G, Rogers J, Murphy CT, Rongo C. EGF signalling activates the ubiquitin proteasome system to modulate C. elegans lifespan. EMBO J. 2011;30:2990-3003.

[45] Vangala GR, Dudem S, Jain N, Kaliventi SD. Regulation of PSMB5 and $\beta$-subunits of mammalian proteasome by constitutively activated STAT3: potential role in Bortezomib mediated anticancer therapy. J Biol Chem. 2014;113:542829.

[46] Adachi S, Yasuda I, Nakashima M, Yamauchi T, Kawaguchi J, Shimizu M, Itani M, Nakamura M, Nishii Y, Yoshioka T, Hirose Y, Okano Y, Moriwaki H, Kozawa O. Ultraviolet irradiation can induce evasion of colon cancer cells from stimulation of epidermal growth factor. J Biol Chem. 2011;286:26178-87.

[47] Moulik S, Sen T, Dutta A, Banerji A, Ghosh C, Das S, Chatterjee A. Phosphatidylinositol 3-Kinase and NF-KB involved in epidermal growth factor-induced matrix metalloproteinase-9 expression. J Cancer Mol. 2008;4(2):55-60.

[48] Le Page C, Koumakpayi IH, Lessard L, Mes-Masson AM, Saad F. EGFR and Her- 2 regulate the constitutive activation of NF-KB in PC-3 prostate cancer cells. Prostate. 2005;65:130-40.

[49] Kapeta S, Chondrogianni N, Gonos ES. Nuclear erythroid factor 2 (Nrf2) mediated proteasome activation delays senescence in human fibroblasts. J Biol Chem. 2010;285(11):8171-84.

[50] Pickering AM, Linder RA, Zhang H, Forman HJ, Davies KJ. Nrf2dependent induction of proteasome and Pa28alphabeta regulator are required for adaptation to oxidative stress. J Biol Chem. 2012;287:10021-31.

[51] Sebens S, Bauer I, Geismann C, Grage-Griebenow E, Ehlers S, Kruse ML, Arlt A, Schäfer H. Inflammatory macrophages induce Nrf2 transcription factor-dependent proteasome activity in colonic NCM460 cells and thereby confer anti-apoptotic protection. J Biol Chem. 2011;286:40911-21.

[52] Arlt A, Bauer I, Schafmayer C, Tepel J, Müerköster SS, Brosch M, Röder C, Kalthoff H, Hampe J, Moyer MP, Fölsch UR, Schäfer H. Increased proteasome subunit protein expression and proteasome activity in colon cancer relate to an enhanced activation of nuclear factor E2-related factor 2 (Nrf2). Oncogene. 2009;28 (45):3983-96.

[53] Papaiahgari S, Zhang Q, Kleeberger SR, Cho HY, Reddy SP. Hyperoxia stimulates an Nrf2-ARE transcriptional response via ROS-EGFR-PI3K-Akt/ERK MAP kinase signaling in pulmonary epithelial cells. Ant Red Sig. 2006;8:43-52.

[54] Zhang DD. Mechanistic studies of the Nrf2-Keap1 signaling pathway. Drug Metab Rev. 2006;38:769-89.

[55] Kraft DC, Deocaris CC, Wadhwa R, Rattan SI. Preincubation with the proteasome inhibitor MG-132 enhances proteasome activity via the Nrf2 transcription factor in aging human skin fibroblasts. Ann NY Acad Sci. 2006;1067:420-4.

[56] Steffen J, Seeger M, Koch A, Krüger E. Proteasomal degradation is transcriptionally controlled by TCF11 via an ERAD-dependent feedback loop. Mol Cell. 2010;40:147-58.

[57] Kwak MK, Wakabayashi N, Greenlaw JL, Yamamoto M, Kensler TW. Antioxidants enhance mammalian proteasome expression through the Keap1-Nrf2 signaling pathway. Mol Cell Biol. 2003;23:8786-94.

[58] Xu H, Fu J, Ha SW, Ju D, Zheng J, Li L, Xie Y. The CCAAT boxbinding transcription factor NF-Y regulates basal expression of human proteasome genes. Biochim Biophys Acta. 2012;1823(4): 818-25.

[59] Lecomte S, Desmots F, Le Masson F, Le Goff P, Michel D, Christians ES, Le Dréan Y. Roles of heat shock factor 1 and 2 in response to proteasome inhibition: consequence on p53 stability. Oncogene. 2010;29(29):4216-24.

[60] Lipkowitz S. The role of the ubiquitination-proteasome pathway in breast cancer. Ubiquitin mediated degradation of growth factor receptors in the pathogenesis and treatment of cancer. Breast Cancer Res. 2003;5:8-15.

\section{COMPETING INTERESTS}

The authors declare no competing interests.

\section{PUBLISHING NOTES}

(C) 2014 M.-I. Ellina et al. This work has been published open access under Creative Commons Attribution License CC BY 4.0, which permits unrestricted use, distribution, and reproduction in any medium, provided the original work is properly cited. Conditions, terms of use and publishing policy can be found at www.scienceopen.com.

Please note that this article may not have been peer reviewed yet and is under continuous post-publication peer review. For the current reviewing status please click here or scan the QR code on the right.

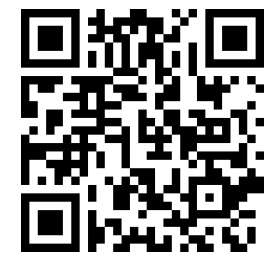

\section{scienceOPEN.com}

